\title{
EFFECT OF YOGURTH ADDUCTION IN BLOOD PRESSURE DEGRESSION ON PREGNANT WOMAN WITH HYPERTENSION
}

\author{
Nita Evrianasari $^{1}$, Ike Ate Yuviska $^{2}$ Suprihatini $^{3}$ \\ Universitas Malahayati Jurusan Kebidanan
}

\begin{abstract}
Background: The immediate factor causing high maternal mortality rate was bleeding (30,3\%), especially post partum bleeding. In addition, hypertension (27.1\%), infection (7.3\%), and long handled parturition (1.7\%) and based on pre-survey data on 27-42018 at public health working regency of Pesawaran occurring 2 people death due to eclampsia. This study aims to determine the effect of giving yogurt to pregnant women with hypertension in the Area of Health Service District Pesawaran Year 2018. Methods: This type of research is quantitative by using the experimental approach (pre experiment) with pretest-posttest approach with control group. The population in this study were all pregnant women with hypertension. Data in this research taken by simple purposive sample with primary data and data analysis using pretest dependent.. Result:The results of this study showed that there was an effect of yogurt on blood pressure reduction, which mean score of sitole blood pressure before yogurt adduction was significantly higher than after yogurt adduction ( $p$ value $0,000<0.005$ ) and the effect of yogurt on blood pressure diastole, where scores on average diastolic blood pressure measurements before yogurt adduction were significantly higher than after adduction of yogurt. Conclusion: There was a significant difference in mean systole and diastole blood pressure in mothers given yogurt than not given yogurt. Hopefully, from this research should be advised so that could prevent the occurrence of pre eclampsia for pregnant women.
\end{abstract}

Keywords: Hypertension,Pregnancy, Yogurt.

\section{PENDAHULUAN}

Kemampuan

kesehatan suatu dengan menentukan tinggi rendahnya angka kematian ibu dan perinatal dalam 100.000 persalinan hidup. Menurut World Health Organization (WHO), kematian maternal kematian seorang wanita waktu hamil atau dalam 42 hari sesudah berakhirnya kehamilan oleh sebab apapun, terlepas dari tuanya kehamilan dan tindakan yang dilakukan untuk mengakhiri kehamilan (Jacob et all, 2017)

Mortalitas dan morbiditas pada wanita hamil dan bersalin adalah masalah besar di Negara berkembang. World Health Organization (WHO) memperkirakan 800 perempuan meninggal setiap harinya akibat komplikasi kehamilan dan proses kelahiran. Sekitar 99\% dari seluruh kematian ibu terjadi di Negara berkembang. Sekitar $80 \%$ kematian maternal merupakan akibat meningkatnya komplikasi selama kehamilan, persalinan dan setelah persalinan (Wulandari et all, 2017)

Faktor langsung penyebab tingginya angka kematian ibu adalah perdarahan $(30,3 \%)$, terutama perdarahan post partum. Selain itu adalah hipertensi (27,1\%), 
infeksi (7,3\%), dan partus lama/macet $(1,7 \%)$. Komplikasi obstetric umumnya terjadi pada waktu persalinan, yang waktunya pendek yaitu sekitar 8 jam (Profil Kesehatan Indonesia, 2014).

Hipertensi merupakan penyulit pada 5-15\% kehamilan dan dapat menyebabkan morbiditas dan mortalitas pada ibu dan janin. Gangguan hipertensi pada kehamilan mencakup berbagai kondisi, termasuk pre-eklampsial eklampsia, hipertensi gestasional, hipertensi kronis dan pre eklampsia yang terjadi pada hipertensi kronis. (Sirait, A. M. (2012). Selain itu dampak dari hipertensi gestasional adalah bayi yang dilahirkan pada saat dewasa mempunyai dampak menderita hipertensi. (Maternity, 2018)

Kehamilan dengan pre eklamsia adalah keadaan dimana hipertensi dengan protein urine, edema atau keduanya yang terjadi akibat kehamilan setelah 20 minggu atau kadang timbul lebih awal. Meskipun secara tradisional diagnosis pre eklamsia memerlukan adanya hipertensi karena kehamilan disertai protein urine atau edema, ada yang mengatakan bahwa edema pada tangan dan muka sangat sering ditemukan pada wanita hamil sehingga diagnosa preeklamsia tidak dapat disingkirkan dengan tidak adanya edema. Insiden preeklamsia pada wanita dengan hipertensi kronik bervariasi karena belum ada definisi yang pasti. (Maternity, D et all, 2016).

Pencegahan hipertensi bisa diatasi dengan 2 cara yaitu dengan farmakologis atau dengan obat- obatan anti hipertensi dengan jangka panjang bahkan seumur hidup, seperti diuretik, (Tablet Hydrochlorothiazide (HCT), Lasix (Furosemide). Maupun dapat menggunakan terapi non farmakologi.
(Jalan et all, 2015)

Terapi non farmokologi dapat menggunakan Yougurt. Yoghurt mengandung kalium, kalsium dan magnesium. Keseimbangan asupan kalium, kalsium dan magnesium dalam tubuh sangat baik untuk menurunkan tekanan darah. Solusi alternatif ini dapat menurunkan tekanan darah sehingga dapat memperingan kerja jantung dalam memompa darah ke seluruh tubuh. Di dalam tubuh, kalium berfungsi untuk memelihara keseimbangan garam (natrium) dan cairan serta membantu mengontrol tekanan darah. Kadar kalium yang rendah akan menyebabkan terjadinya retensi natrium dalam tubuh. Kondisi ini dapat menyebabkan tekanan darah mengalami peningkatan. Dengan menerapkan diet tinggi kalium dapat menurunkan dosis obat hipertensi yang dibutuhkan. Yogurt yang berisi susu fermentasi bekerja dengan bakteri Lactobacillus mengurai protein, sehingga dapat menurunkan aktivitas angiotensin converting ezym, menyebabkan tekanan darah turun (Diana, S. (2016).

\section{METODE PENELITIAN}

Dalam penelitian ini mengunakan jenis penelitian kuantitaif, penelitian dilakukan pada bulan Maret s.d Juli 2018, dilakukan di 4 Kecamatan Wilayah Kerja Dinas Kesehatan Kabupaten Pesawaran. Rancangan penelitian yang digunakan eksperimen (preeksperiment) dengan pendekatan pretest-posttest with kontrol group, dimana dalam rancangan ini seperti rancangan pretest posttest, dan memiliki group kontrol.

Populasi dalam penelitian ini adalah semua ibu hamil dengan hipertensi antara tekanan darah systole $140 \mathrm{mmHg}$ dan diastole $>90 \mathrm{mmHg}$ yang ada di 
Kecamatan Padang Cermin, punduh pidada, teluk pandan dan way ratai yaitu sebanyak 61 orang.

Penentuan jumlah sampel dalam penelitian ini berdasarkan konsep dan penerapan metodelogi penelitian oleh Sugiyono (2014) menyatakan bahwa lima belas subjek pada setiap kelompok dianggap minimum untuk riset eksperimental. Sepuluh sampai dua puluh subjek per kelompok dianggap minimum untuk studi yang simple dengan kontrol yang kuat. Sehingga sampel dalam penelitian ini adalah ibu hamil dengan hipertensi yang pada saat dilakukan penelitian, yang memenuhi criteria sampel yaitu sebanyak 30 orang, 15 orang sebagai kelompok eksperimen dan 15 orang sebagai kelompok Kontrol.

\section{HASIL PENELITIAN}

\section{Karakteristik Responden}

Tabel 1. Karakteristik Responden

\begin{tabular}{lrc}
\hline Karakteristik & N & \% \\
\hline Umur & 25 & 83,3 \\
$20-35$ tahun & 5 & 16,7 \\
$<20$ tahun dan $>35$ tahun & $\mathbf{3 0}$ & $\mathbf{1 0 0}$ \\
\hline Total & & \\
\hline Pekerjaan & 23 & 76,7 \\
Tidak Bekerja & 7 & 23,3 \\
Bekerja & $\mathbf{3 0}$ & $\mathbf{1 0 0}$ \\
\hline Total & &
\end{tabular}

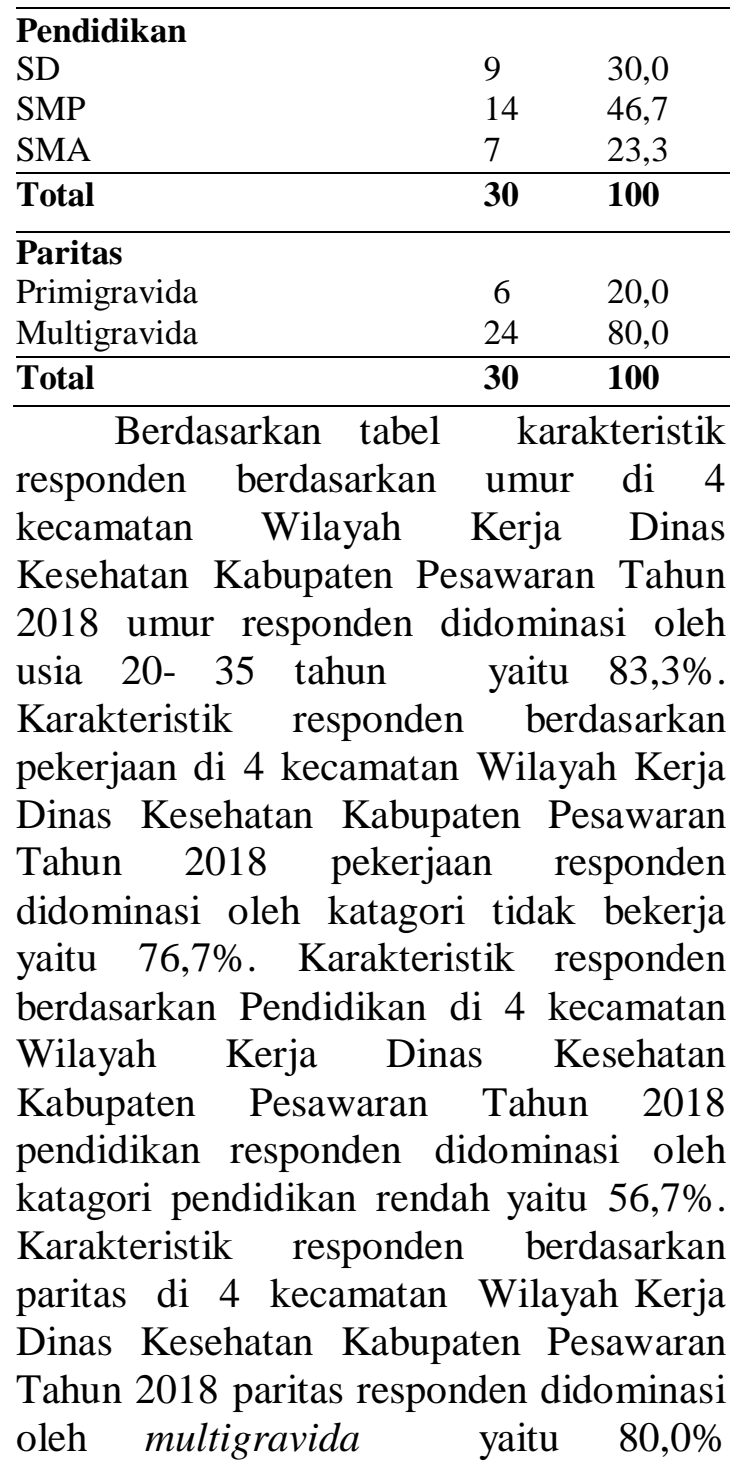




\section{Analisis Univariat}

Tabel 2. Rata-Rata Tekanan Darah Sistole dan Diastole Sebelum dan Sesudah Pemberian Yogurt.

\begin{tabular}{|c|c|c|c|c|c|c|c|c|}
\hline Variabel & $\mathbf{N}$ & Mean & SE & Median & Min & Max & SD & CI:95\% \\
\hline $\begin{array}{l}\text { Skor } \\
\text { tekanan darah } \\
\text { sistole } \\
\text { sebelum } \\
\text { Pemberian } \\
\text { yoghurt (pre } \\
\text { test) }\end{array}$ & 15 & 146,67 & 2,10 & 140,0 & 140,0 & 160,0 & 8,16 & $\begin{array}{l}142,14- \\
151,18\end{array}$ \\
\hline $\begin{array}{l}\text { Skor } \\
\text { tekanan darah } \\
\text { diastole } \\
\text { sebelum } \\
\text { pemberian } \\
\text { yoghurt ( pre } \\
\text { test) }\end{array}$ & 15 & 94,00 & 1,11 & 95,00 & 90,0 & 100,0 & 4,31 & $\begin{array}{l}75,80- \\
81,52\end{array}$ \\
\hline \multicolumn{9}{|c|}{ Sistole dan Diastole Sesudah 14 hari Pemberian Yogurt } \\
\hline $\begin{array}{l}\text { Skor } \\
\text { tekanan darah } \\
\text { sistole } \\
\text { sesudah } \\
\text { pemberian } \\
\text { yoghurt } \\
\text { (post test) }\end{array}$ & 15 & 15 & 134,66 & 1,91 & 130,0 & 120,0 & 150,0 & 7,43 \\
\hline $\begin{array}{l}\text { Skor } \\
\text { tekanan darah } \\
\text { diastole } \\
\text { sesudah } \\
\text { pemberian } \\
\text { yoghurt (post } \\
\text { test) }\end{array}$ & 15 & 78,66 & 1,33 & 80,0 & 70,0 & 90,0 & 5,16 & $\begin{array}{l}75,80- \\
81,52\end{array}$ \\
\hline
\end{tabular}
test)

Berdasarkan tabel di atas, dapat dijelaskan bahwa sebelum pemberian yoghurt (pre-test), rata - rata skor tekanan darah sistole adalah 146,67 dengan standar deviasi 8,16 Nilai terkecil yaitu 140,0 dan nilai maksimum adalah 160,0. Dari hasil estimasi interval dapat disimpulkan bahwa 95\% diyakini bahwa rata-rata skor tekanan darah sistole sebelum yogurt adalah diantara 142,14 sampai dengan 151,18, sedangkan rata - rata skor tekanan darah diastole sebelum pemberian yogurt adalah 94,00 dengan standar deviasi 4,31. Nilai terkecil yaitu 90,0 dan nilai

maksimum adalah 100,0. Dari hasil estimasi interval dapat disimpulkan bahwa 95\% diyakini bahwa rata-rata skor tekanan darah diastol sebelum pemberian yogurt adalah diantara 75.80 dengan 81.52 ,

Sesudah pemberian yogurt (poste-test), rata - rata skor tekanan darah sistole menurun yaitu 134,66 dengan standar deviasi 7,43. Nilai terkecil yaitu 120,0 dan nilai maksimum adalah 150,0. Dari hasil estimasi interval dapat disimpulkan bahwa $95 \%$ diyakini bahwa rata-rata skor tekanan darah sistole sesudah pemberian yogurt adalah diantara 130,55 sampai dengan 138,78 sedangkan rata - rata skor tekanan darah diastole adalah 78,66 dengan standar deviasi 7,20. Nilai terkecil 
yaitu 70,0 dan nilai maksimum adalah interval dapat disimpulkan bahwa 95\% diyakini bahwa rata-rata skor tekanan darah diastole sesudah
90,0. Dari hasil estimasi pemberian yogurt adalah diantara 75,80 sampai dengan 81,52 .

Tabel 3 . Rata - Rata Tekanan Darah Sistole dan Diastole Sebelum dan Sesudah (Kelompok Kontrol)

\begin{tabular}{|c|c|c|c|c|c|c|c|c|}
\hline Variabel & $\mathbf{N}$ & Mean & SE & Median & Min & $\operatorname{Max}$ & SD & $\begin{array}{c}\text { CI:95 } \\
\%\end{array}$ \\
\hline $\begin{array}{l}\text { Skor } \\
\text { tekanan darah } \\
\text { sistole sebelum } \\
\text { ( pre test) }\end{array}$ & 15 & 152,33 & 3,61 & 150,0 & 140,0 & 180,0 & 13,99 & $\begin{array}{c}144,5 \\
8- \\
160,0 \\
8\end{array}$ \\
\hline $\begin{array}{l}\text { Skor } \\
\text { tekanan darah } \\
\text { diastole sebelum } \\
\text { pada kelompok } \\
\text { control ( pre } \\
\text { test) }\end{array}$ & 15 & 94,00 & 1,11 & 90,00 & 90,0 & 100,0 & 4,31 & $\begin{array}{c}91,61- \\
96,38\end{array}$ \\
\hline
\end{tabular}

Sistole dan Diastole Sesudah

\section{Skor}

tekanan darah

sistole sesudah

(post test)

pada kelompok

control

Skor

tekanan darah

diastole sesudah

pada Kelompok

Control (post

test)

Berdasarkan tabel di atas, dapat dijelaskan bahwa rata - rata skor tekanan darah sistole saat (pre-test) adalah 152,0 dengan standar deviasi 14,36. Nilai terkecil yaitu 135,0 dan nilai maksimum adalah 180,0. Dari hasil estimasi interval dapat disimpulkan bahwa 95\% diyakini bahwa rata-rata skor tekanan darah sistole sebelum yogurt adalah diantara 144,04 sampai dengan 159,95 . Sedangkan rata rata skor tekanan darah diastole sebelum (pre-test), pada kelompok kontrol adalah 94,0 dengan standar deviasi 4,31. Nilai terkecil yaitu 90,0 dan nilai maksimum adalah 100,0. Dari hasil estimasi interval dapat disimpulkan bahwa 95\% diyakini bahwa rata-rata skor tekanan darah diastole sebelum pada kelompok kontrol adalah diantara 91,61 sampai dengan 96,38. Rata - rata skor tekanan darah sistole pada kelompok kontrol saat (poste- test) meningkat yaitu 153,66 dengan standar deviasi 15,64. Nilai terkecil yaitu 140,0 dan nilai maksimum adalah 180,0. Dari hasil estimasi interval dapat disimpulkan bahwa 95\% diyakini bahwa rata-rata skor tekanan darah sistole sesudah pemberian yogurt, sedangkan rata - rata skor tekanan darah diastole pada kelompok kontrol saat (post-test) adalah 91,67 dengan standar deviasi 5,23. Nilai terkecil yaitu 80,0 dan nilai 
maksimum adalah 100,0. Dari hasil estimasi interval dapat disimpulkan bahwa $95 \%$ diyakini bahwa rata-rata skor tekanan darah diastole sesudah pada kelompok kontrol adalah diantara 88,77 sampai dengan 94,5.

\section{Analisis Bivariat}

Tabel 4. Pengaruh Tekanan Darah Sistole Pada Kelompok Intervensi

\begin{tabular}{|c|c|c|c|c|c|c|}
\hline \multicolumn{2}{|c|}{ Variabel } & Mean & $S D$ & $S E$ & P.Value & $N$ \\
\hline \multirow{2}{*}{$\begin{array}{c}\text { Tekanan Darah } \\
\text { Sistole }\end{array}$} & Diberikan yogurt & 134,67 & 7,43 & 1,9 & \multirow{2}{*}{0,000} & \multirow{2}{*}{30} \\
\hline & $\begin{array}{l}\text { Tidak diberikan } \\
\text { yogurt }\end{array}$ & 153,67 & 15,63 & 4,03 & & \\
\hline
\end{tabular}

Berdasarkan tabel 4 di atas 153,67 dengan standar deviasi 15,63.

dapat diketahui bahwa pada hasil Pada hasil uji statistik didapatkan nilai $p$ analisis diperoleh jumlah rata - rata - value $0,000<\square 0,05$ maka dapat tekanan darah sistole pada ibu yang disimpulkan bahwa terdapat pengaruh diberikan yogurt adalah 134,67 dengan yang signifikan rata- rata tekanan darah standar deviasi 7,43 sedangkan rata- sistole pada ibu yang diberikan yogurt rata tekanan darah sistole pada ibu dengan yang tidak diberikan yogurt. yang tidak diberikan yogurt adalah

Tabel 5. Pengaruh Tekanan Darah Diastole Pada Kelompok Intervensi

\begin{tabular}{|c|c|c|c|c|c|c|}
\hline \multicolumn{2}{|c|}{ Variabel } & Mean & \multirow{2}{*}{$\frac{S \boldsymbol{D}}{4,14}$} & \multirow{2}{*}{$\begin{array}{c}\boldsymbol{S E} \\
1,07\end{array}$} & Value & \\
\hline \multirow{2}{*}{$\begin{array}{c}\text { Tekanan Darah } \\
\text { Diastole }\end{array}$} & Diberikan yogurt & \multirow{2}{*}{$\begin{array}{r}82,0 \\
91,67\end{array}$} & & & \multirow[b]{2}{*}{0,000} & \multirow[b]{2}{*}{30} \\
\hline & $\begin{array}{l}\text { Tidak diberikan } \\
\text { yogurt }\end{array}$ & & 5,23 & 1,35 & & \\
\hline \multicolumn{2}{|c|}{$\begin{array}{l}\text { Berdasarkan tabel } 5 \text { di atas dapat } \\
\text { diketahui bahwa pada hasil analisis } \\
\text { diperoleh jumlah rata - rata tekanan } \\
\text { darah diastole pada ibu yang diberikan } \\
\text { yogurt adalah } 82,00 \text { dengan standar } \\
\text { deviasi } 4,14 \text { sedangkan rata-rata tekanan } \\
\text { darah diastole pada ibu yang tidak }\end{array}$} & \multicolumn{5}{|c|}{$\begin{array}{l}\text { standar deviasi 5,23. Pada hasil uj } \\
\text { statistik didapatkan nilai p-value } 0,000 \\
<\quad \square \square 0,05 \text { maka dapat disimpulkar } \\
\text { bahwa terdapat pengaruh yang } \\
\text { signifikan rata-rata tekanan darah } \\
\text { diastole pada ibu yang diberikan yogur } \\
\text { dengan yang tidak diberikan yogurt }\end{array}$} \\
\hline
\end{tabular}

\section{PEMBAHASAN}

\section{Analisis Univariat}

a. Distribusi Rata - Rata Tekanan Darah Pada Kelompok Yang Diberikan Intervensi

Berdasarkan hasil penelitian, dapat dijelaskan bahwa sebelum pemberian yogurt (pre-test), rata - rata skor tekanan darah sistole adalah 146,67 dengan standar deviasi 8,16 dan diastole sebelum pemberian yogurt adalah 94,00 dengan standar deviasi 4,31. Sedangkan sesudah pemberian yogurt rata - rata skor tekanan darah sistole menurun yaitu 134,66 dengan standar deviasi 7,43 dan rata rata skor tekanan darah diastole adalah 78,66 dengan standar deviasi 7,20. 
Tekanan darah tinggi atau hipertensi berarti tekanan tinggi di dalam arteriarteri. Arteri-arteri adalah pembuluhpembuluh yang mengangkut darah dari jantung yang memompa keseluruh jaringan dan organ-organ tubuh. Tekanan darah tinggi bukan berarti tegangan emosi yang berlebihan, meskipun tegangan emosi dan stres dapat meningkatkan tekanan darah untuk sementara waktu. Tekanan darah normal adalah di bawah 120/80 mmHg, tekanan darah antara 120/80 dan 139/89 disebut "prahipertensi" ("pre-hypertension"), dan suatu tekanan dari 140/90 atau di atasnys dianggap tinggi (Muhammadun, 2010).

Yoghurt merupakan hasil dari fermentasi susu yang dapat menurunkan tekanan darah. Didalam yoghurt terdapat karbohidrat, gula, protein, kalsium, kalium, asam laktat, fosfor, seng, yodium, riboflavin, serta vitamin A, B2, B5, dan B2 dan D (Sirajudin et all, 2005).

Hasil ini sejalan dengan penelitian yang dilakukan oleh Penelitian yang telah dilakukan oleh Sulis dengan judul "Pengaruh Terapi Non Farmakologi Yogurt Terhadap Penurunan Tekanan Darah Ibu Hamil Hipertensi Di Puskesmas Gayaman Kecamatan Gayaman Kab. Mojokerto", dengan hasil penelitian Hasil uji wilcoxon menunjukkan bahwa nilai $\mathrm{Z}$ hitung sama dengan -2,489 dengan $\mathrm{p}$ value $(0,013)$ $<\square(0,05)$ sehingga Ho ditolak jadi ada perbedaan tekanan darah sebelum dan sesudah diberi terapi yoghurt.

Menurut pendapat peneliti tekanan darah responden sebelum dan sesudah pemberian yogurt mengalami penurunan dikarenakan kandungan yogurt yang sangat baik. Faktor yang berhubungan dengan hipertensi pada kehamilan salah satunya adalah usia, pada penelitian ini ada 5 responden dalam katagori usia beresiko yaitu < 18 tahun dan $>35$ tahun.

\section{b. Distribusi Rata - Rata Tekanan Darah Pada Kelompok Kontrol}

Hasil penelitian menjelaskan bahwa rata - rata skor tekanan darah sistole saat(pre-test) adalah 152,0 dengan standar deviasi 14,36, dan rata - rata skor tekanan darah diastole sebelum (pre-test), pada kelompok kontrol adalah 94,0 dengan standar deviasi 4,31, sedangkan rata - rata skor tekanan darah sistole pada kelompok kontrol saat (poste-test) meningkat yaitu 153,66 dengan standar deviasi 15,64 rata - rata skor tekanan darah diastole pada kelompok kontrol saat (post-test) adalah 91,67 dengan standar deviasi 5,23.

Nilai normal tekanan darah seseorang yang disesuaikan tingkat aktifitas dan keseatan secara umum adalah 120/80 mmHg. Tetapi secara umum, angka pemeriksaan tekanan darah menurun saat tidur dan meningkat saat beraktifitas atau berolahraga (Rukiyah, 2010). Hipertensi karena kehamilan yaitu : hipertensi yang terjadi karena atau pada saat kehamilan dapat mempengaruhi kehamilan itu sendiri biasanya terjadi pada usia kehamilan memasuki 20 minggu (Rukiyah, 2010).

Menurut pendapat peneliti peningkatan tekanan darah responden dipengaruhi oleh faktor genetik dan gaya hidup seseorang, dimana pada penelitian ini gaya hidup dan faktor genetik tidak dibatasi.

2. Pengaruh Tekanan Darah Pada Kelompok Intervensi Pemberian Yoghurt Dan Kelompok Kontrol Terhadap Ibu Hamil Dengan 
Tekanan Darah Tinggi (Analisis Bivariat).

Berdasarkan hasil penelitian diperoleh rata - rata tekanan darah sistole pada ibu yang diberikan yogurt adalah 134,67 dengan standar deviasi 7,43 sedangkan rata-rata tekanan darah sistole pada ibu yang tidak diberikan yogurt adalah 153,67 dengan standar deviasi 15,63. Pada hasil uji statistik didapatkan nilai $p$-value $0,000<$ 0,05 maka dapat disimpulkan bahwa terdapat perbedaan yang signifikan rata- rata tekanan darah sistole pada ibu yang diberikan yogurt dengan yang tidak diberikan yogurt, sedangkan rata - rata tekanan darah diastole pada ibu yang diberikan yoghurt adalah 82,00 dengan standar

deviasi 4,14 sedangkan rata-rata tekanan darah diastole pada ibu yang tidak diberikan yoghurt adalah 91,67 dengan standar deviasi 5,23. Pada hasil uji statistik didapatkan nilai $p$ value $0,000<\square 0,05$ maka dapat disimpulkan bahwa terdapat perbedaan yang signifikan rata- rata tekanan darah diastole pada ibu yang diberikan yogurt dengan yang tidak diberikan yogurt. Hipertensi karena kehamilan yaitu : tekanan darah yang lebih tinggi dari 140/90mmHg yang disebabkan karena kehamilan itu sendiri, memiliki potensi yang menyebabkan gangguan serius pada kehamilan (Rukiyah 2010).

Hipertensi yaitu peningkatan tekanan sistolik sekurang- kurangnya $30 \mathrm{mmHg}$ atau peningkatan tekanan diastolik sekurang-kurangnya 15 $\mathrm{mmHg}$, atau adanya tekanan sistolik sekurang-kurangnya $140 \mathrm{mmHg}$ dan tekanan diastolik sekurang-kurangnya $90 \mathrm{mmHg}$. Hipertensi juga dapat ditentukan dengan tekanan arteri rata-rata $105 \mathrm{~mm} \mathrm{Hg}$ atau lebihatau dengan kenaikan $20 \mathrm{mmHg}$ atau lebih nilainilai yang disebutkan diatas harus bermanifesti sekurang- kurangnya dua kesempatan dengan perbedaan waktu 6 jam atau lebih dan harus didasarkan pada nilai tekanan darah sebelumnya yang diketahui (Rukiyah,2010).

Hipertensi

kehamilan berkembangnya hipertensi selama kehamilan atau 24 jam pertama postpartum pada seseorang yang sebelumnya normotensi. Tak ada petunjuk - petunjuk lain dari pre-eklamsia atau penyakit vaskuler hipertensi. Tekanan darah kembali dalam batas noramal dalm sepuluh hari setelah persalinan. Beberapa pasien dengan hipertensi kehamilan sebenarnya mungkin mengidap preeklamsia atau penyakit vaskuler hipertensi, tetapi mereka tidak mempunyai kriteria untuk diagnosis ini (Rukiyah, 2010).

Terapi non farmakologi lebih aman untuk ibu dan janin antara lain dengan konsumsi yogurt sebanyak 2-3 kali sehari minimal $142 \mathrm{ml} / \mathrm{hari}$ dan maksimal $1600 \quad \mathrm{ml} / \mathrm{hari}$ dapat menurunkan tekanan darah pada ibu hamil dengan hipertensi (Diana, S. (2016).

Dong (2013) mengungkapkan bahwa studi membuktikan bahwa konsumsi yoghurt (susu sapi fermentasi) dapat menurunkan tekanan darah sistol hingga $3 \mathrm{mmHg}$ secara signifikan dan menurunkan $1 \mathrm{mmHg}$ pada tekanan darah diastolik. Hasil ini akan lebih baik jika ditambahkan pengontrolan diet makan dimana mengkonsumsi buah, sayur dan makan rendah lemak.

Sementara menurut Asemi (2013) kekurangan kalsium, magnesium, natrium 
dan magnesium adalah faktor predisposisi terjadinya hipertensi pada kehamilan. Maka diet pengelolaan konsumsi natrium, magnesium, kalsium dalam bentuk susu, fermentasi susu (yoghurt), keju, kedelai produk, sayuran berdaun, selama kehamilan, dapat pengurangan kejadian hipertesi.

Menurut pendapat peneliti Pada dasarnya Yoghurt merupakan salah satu menu makanan sebagai solusi alternatif untuk menurunkan tekanan darah pada ibu hamil hipertensi. Yoghurt mengandung kalium, kalsium dan magnesium. Keseimbangan asupan kalium, kalsium dan magnesium dalam tubuh sangat baik untuk menurunkan tekanan darah. Solusi alternatif ini dapat menurunkan tekanan darah sehingga dapat memperingan kerja jantung dalam memompa darah ke seluruh tubuh. Oleh karena itu, disarankan konsumsi yoghurt tidak hanya pada ibu hamil yang mengalami hipertensi, tetapi juga pada ibu hamil yang mempunyai tekanan darah normal. Selain itu bahwa secara teori fakrtor resiko pre eklamsi umumnya terjadi pada responden dengan usia < 20 tahun dan > 35 tahun dan dengan paritas grande multipara dalam penelitian aini hanya ditemukan 2 responden dengan paritas beresiko dan 1 ibu dengan kehamilan pertama dengan usia muda. hipertensi tidak akan muncul begitu saja naiknya tekanan darah biasanya terakumulasi dikarenakan gaya hidup yang tidak sehat dalam waktu yang lama.

\section{KESIMPULAN DAN SARAN}

Kesimpulan:

Ada pengaruh yang signifikan rata- rata tekanan darah sistole dan diastole pada ibu yang diberikan yoghurt dengan yang tidak diberikan yoghurt.
Saran:

Disarankan kepada masyarakat khususnya ibu hamil yang menderita hipertensi lebih banyak mendapat perbendaharaan obat non farmakologi khususnya yoghurt. Karena disamping untuk menurunkan tekanan darah terdapat pula kandungan vitamin yang dibutuhkan untuk ibu hamil dan janinnya. Meskipun harga yoghurt cukup mahal, tetapi banyak sekali manfaatnya. Seperti kandungan kalsium, magnesium, kalium yang memang dapat mengontrol resorbsi atau keseimbangan garam atau natrium dalam tubuh, kandungan vitamin B1 dan B12 yang diperlukan untuk menjaga selsel darah merah dan menjaga fungsi kerja system saraf, dan masih banyak manfaat lainnya.

Bagi peneliti selanjutnya diharapkan dapat dijadikan sebagai bahan masukan untuk menambah koleksi buku - buku bacaan dan jurnal penelitian yang mendukung dalam proses penelitian selanjutnya dengan kondisi wilayah yang berbeda dan metode yang berbeda dan dengan membandingkan 2 metode agar lebih efektif.

\section{DAFTAR RUJUKAN}

Asemi, Z., Samimi, M., Tabassi, Z., Rad, M. N., Foroushani, A. R., Khorammian, H., \& Esmaillzadeh, A. 2013. Effect of daily consumption of probiotic yoghurt on insulin resistance in pregnant women: a randomized controlled trial. European journal of clinical nutrition, 67(1), 71.

Dainty Maternity, S. S. T., Keb, M., Anjani, A. D., \& Kes, M. 2018. ASUHAN KEBIDANAN NEONATUS, BAYI, BALITA, DAN 
ANAK PRASEKOLAH. Penerbit Andi.

Diana, S. 2016. "Peer Review Prosiding"

Pengaruh Terapi Non Farmakologi

Yogurt terhadap Penurunan Tekanan

Darah Ibu Hamil Hipertensi di

Puskesmas Gayaman Kecamatan

Gayaman Kabupaten

Mojokerto". PENELITIAN DOSEN.

Jacob, F. K., Engkeng, S., \& Adam, H. 2017.

HUBUNGAN

PENGETAHUAN, PENDIDIKAN

DAN SIKAP IBU HAMIL

DENGAN PEMERIKSAAN

KEHAMILAN DI WILAYAH

KERJA PUSKESMAS TUMPAAN

KABUPATEN MINAHASA

SELATAN. KESMAS, 6 (4).

Jalan, J. K. P. K. P., \& Padang, G. M. G. P.2015. PEMBERIAN AIR SEDUHAN BAWANG PUTIH TERHADAP PENURUNAN

TEKANAN DARAH Mohanis.

Kementerian Kesehatan, R. I. (2014). Profil kesehatan indonesia. Diakses dari http://www. kemkes. go. id.

Maternity, D., Dewi, P. R., \& Yuli, Y. 2016. Asuhan Kebidanan Persalinan. Tangerang Selatan: Binarupa Aksara Publisher.

Muhammadun, A. S. 2010. Hidup bersama hipertensi. Yogyakarta: InBooks.

Rukiyah, A. Y. 2010. Asuhan Kebidanan Patologi Kebidanan 4. Jakarta Timur: CV. Trans Info Media.

Sirait, A. M. 2012. Prevalensi Hipertensi Pada Kehamilan di Indonesia dan Berbagai Faktor Yang Berhubungan (Riset Kesehatan Dasar 2007). Buletin Penelitian Sistem Kesehatan, 15(2).
Surajudin, F. R. K., \& Purnomo, D. 2005. Yoghurt; Susu Fermentasi yg Menyehatkan. Agro Media.

Wulandari, P., \& Hiba, P. D. N.2018. Pengaruh Massage Effleurage Terhadap Pengurangan Tingkat Nyeri Persalinan Kala I Fase Aktif pada Primigravida di Ruang Bougenville Rsud Tugurejo Semarang. Jurnal Keperawatan Maternitas, 3(1), 59-67. 